\title{
EXPERIMENTAL INVESTIGATION OF PERFORMANCE OF PLATE HEAT EXCHANGER FOR WATER AS WORKING FLUID
}

\author{
Tambe Shahanwaj K $\mathbf{1}^{1}$, Pandhare Nitin $\mathbf{T}^{\mathbf{2}}$, Bardeskar Santosh $\mathbf{J}^{\mathbf{3}}$, Khandekar S.B ${ }^{\mathbf{4}}$

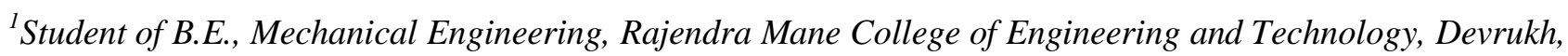 \\ Maharashtra, India \\ ${ }^{2}$ Student of B.E., Mechanical Engineering, Rajendra Mane College of Engineering and Technology, Devrukh, \\ Maharashtra, India \\ ${ }^{3}$ Student of B.E., Mechanical Engineering, Rajendra Mane College of Engineering and Technology, Devrukh, \\ Maharashtra, India \\ ${ }^{4}$ Assistant professor, Mechanical Engineering, Rajendra Mane College of Engineering and Technology, Devrukh, \\ Maharashtra, India
}

\begin{abstract}
Compact heat exchangers are most widely used for heat transfer applications in industries. Plate heat exchanger is one such compact heat exchanger, provides more area for heat transfer between two fluids in comparison with shell and tube heat exchanger. Plate type heat exchangers are widely used for liquid-to-liquid heat transfer applications with high density working fluids. This study is focused on use of plate type heat exchanger for water as a working fluid. This research work deals with experimental investigation of plate type heat exchanger with evaluation of convective heat transfer coefficient, overall heat transfer coefficient, exchanger effectiveness. The heat exchanger used for carrying out this work consists of thin metal welded plates of stainless steel with $1 \mathrm{~mm}$ thickness, rectangular geometry and distance between two plates is $7 \mathrm{~mm}$. This test setup consists of total 16 numbers of plates and it is designed to withstand with $85^{\circ} \mathrm{C}$ temperature, pressure drop is neglected. Tests are conducted by varying operating parameters like mass flow rate, inlet temperatures of hot water. The main objective of this work is to find effects of these parameters on performance of plate heat exchanger with parallel flow arrangement. Results show that, overall heat transfer coefficient and convective heat transfer coefficient increases with increase in mass flow rate and Reynolds number. Also the effectiveness varies slightly with heat capacity ratio. In this study, maximum effectiveness achieved for plate heat exchanger with water as a working fluid is 0.48. Use of plate heat exchanger is more advantageous than the tube type heat exchanger with same effectiveness, as it occupies less space.
\end{abstract}

Keywords: Plate heat exchanger, Convective heat transfer coefficient, Effectiveness, Overall heat transfer coefficient, Reynolds number.

\section{INTRODUCTION}

Heat exchanger is a device in which transfer of thermal energy takes place between two of more fluids across a solid surface. These exchangers are classified according to construction, flow arrangement; number of fluids, compactness, etc. The use of heat exchanger gives higher thermal efficiency to the system. In many applications like power plants, petrochemical industries, air conditioning etc. heat exchangers are used. Plate heat exchanger is generally used in dairy industry due to its ease of cleaning and thermal control. The plate heat exchangers are built of thin metal heat transfer plates and pipe work is used to carry streams of fluid. Plate heat exchangers are widely used in liquid to liquid heat transfer and not suitable for gas to gas heat transfer due to high pressure drop.

R. K. Shah and S. G. Kandilkar, have experimentally investigated the influence of number of thermal plates on effectiveness of heat exchanger for 1 pass 1,2 pass 1,3 pass 1 flow arrangements and number of plates up to 41 . Results were plotted for number of plates and F, NTU and F, for different pass arrangements. They concluded, for 1pass1 flow arrangement with an even number of thermal plates, fluid in the outermost channels is same. The heat transfer rate of multi pass arrangement may be higher or lower than that of 1pass 1 for same $\mathrm{N}$ and $\mathrm{R}$ which depends upon heat transfer characteristics of plate material. For $\mathrm{N}<40$, end effect is considerable. When there is significant imbalance in flow rates, $\mathrm{R}<2$, 1pass 1 arrangement is desirable. For $(\mathrm{R}=2,3)$ 2pass1 arrangement is desirable and for $\mathrm{R}>4,3$ pass 1 arrangement is desirable and for 1 pass 1 exchanger with an even number of thermal plates the fluid in outermost channel is same. The exchanger effectiveness is slightly higher if outer fluid has higher heat capacity as compared to other fluid having one less flow channel. [1]

H. Dardour, S. Mazouz, and A. Bellagi had done numerical analysis of the thermal performance of a plate type heat exchanger with parallel flow configuration. The computation is based on the effectiveness- NTU model. The numerical results illustrate the evolution of the most important parameters of the plate heat exchanger. A 
parametric analysis is presented which brings out the effect of NTU and the R parameter, the heat capacity rate ratio, on the performance of the plate heat exchanger (PHE). To check the validity of the presented simplified model established to describe the energy balances in the PHE and the numerical scheme adopted, simulated performance has been compared to the performance evaluated by theoretical relations. Comparison shows an excellent agreement between them. The temperature gradients through each channel and heat fluxes through each active plate are also evaluated. [2]

Murugesan M.P. and Balasubramani R. had done the test for the investigation of milk adhesion and the stability of the coatings on corrugated plates. A number of coatings and surface treatments were tested. Heat exchanger plates coated with different nano-composites as well as electro polished plates installed in the heating section of the pasteurizer were tested. Significant differences were observed between coated and uncoated plates. The coated plates showed that reduced deposit buildup in comparison with the uncoated stainless steel plates. The time required for cleaning place with the coated plates was reduced by $75 \%$ compared to standard stainless steel plates. [3]

Murugesan M.P. and Balasubramani R. had experimentally investigated heat transfer performance of plate type heat exchanger by varying operating parameters and design parameters. Heat transfer coefficient was studied for various fluids like water and ethylene glycol. The increase mass flow rate with subsequently increase in the flow velocity has led to an increased overall heat transfer coefficient as well as individual heat transfer coefficient. [4]

T K S Sai Krishna, S G Rajasekhar, C Pravarakhya modeled the plate type heat exchanger in solid works and the fluid flow analysis is done on the modeled fluid part. The analysis stated that when the thickness of the plates decreases then the heat flow is higher and if the number of plates increases then the outlet temperature difference of the fluids increased and the pressure contour stated that, there is little pressure drop in the entry and outlet of the fluid, From the turbulent contour it is interfered that there is very high turbulence in the entry and outlets due to sudden change in cross section along the plates. [5]

This paper focuses on thermal design of plate heat exchanger for one pass one arrangement and water-water heat transfer. The main objective of this paper is performance analysis of plate heat exchanger with regard to overall heat transfer coefficient, effectiveness.

\section{METHODOLOGY}

\subsection{Thermal Design}

Design procedure of heat exchange involves rating and sizing of heat exchanger. Rating problem deals with determination of rate of heat transfer, heat transfer coefficient, outlet temperature. Sizing problem involves selection of plate material, flow arrangement, determining physical size of heat exchanger to meet specified heat transfer. Plate heat exchanger used for carrying out this research work comprises plane steel plates with material as $X Y Z$. This heat exchanger design involves calculation of heat transfer coefficient and physical size in terms of plate dimensions and number of plates with following information:

Hot water inlet temp $=85^{\circ} \mathrm{C}$,

Hot water outlet temp $=65^{\circ} \mathrm{C}$, Cold water inlet temp $=30^{\circ} \mathrm{C}$ Mass flow rate of hot water $m_{h}=0.3 \mathrm{~kg} / \mathrm{sec}$, and mass flow rate of cold water $m_{c}=0.3 \mathrm{~kg} / \mathrm{sec}$

\subsubsection{Heat Duty $(Q)$}

Heat duty is defined as the product of mass flow rate specific heat capacity and the temperature difference between inlet and outlet fluid temperatures.

$$
Q=m C_{p} \Delta T
$$

Heat rejected by hot water

$$
\begin{gathered}
Q=m_{h} C_{p h} \Delta T_{h} \\
Q=m_{h} C_{p h}\left(T_{h 1}-T_{h 2}\right) \\
=0.3 \times 4.193 \times 20 \\
=25158 \mathrm{~W}
\end{gathered}
$$

Where, $\mathrm{m}_{\mathrm{h}}=$ mass flow rate of hot water in $\mathrm{Kg} / \mathrm{s}$, $\mathrm{C}_{\mathrm{ph}}=$ specific heat capacity of hot water $\mathrm{J} / \mathrm{Kg} \mathrm{K}$, $\Delta \mathrm{T}_{\mathrm{h}}=$ temperature difference between inlet and outlet of hot water in $\mathrm{K}$

Heat absorbed by cold water

$$
\begin{gathered}
Q=m_{c} C_{p c} \Delta T_{c} \\
=m_{c} C_{p c}\left(T_{c 2}-T_{c 1}\right) \\
25158=0.3 \times 4.179 \times(T c 2-30) \\
T_{c 2}=50^{\circ} \mathrm{C}
\end{gathered}
$$

Where, $\mathrm{m}_{\mathrm{c}}=$ mass flow rate of cold water in $\mathrm{Kg} / \mathrm{s}$, $\mathrm{C}_{\mathrm{pc}=}$ specific heat capacity of hot water in $\mathrm{J} / \mathrm{Kg} \mathrm{K}$, $\Delta \mathrm{T}_{\mathrm{c}}=$ Temperature difference between inlet and outlet of cold water in $\mathrm{K}$

Hot water mean temp $=\frac{85+65}{2}=75^{\circ} \mathrm{C}$
Cold water mean temp $=\frac{30+50}{2}=40^{\circ} \mathrm{C}$ 
Table -1: Properties of water at mean temperature [10]

\begin{tabular}{|l|l|l|l|}
\hline Property & $\begin{array}{l}\text { Unit } \\
(\text { metric) }\end{array}$ & $\begin{array}{l}\text { Hot water } \\
\text { (mean } \\
\text { temp) }\end{array}$ & $\begin{array}{l}\text { Cold water } \\
\text { (mean } \\
\text { temp) }\end{array}$ \\
\hline $\begin{array}{l}\text { Heat capacity } \\
\left(\mathrm{C}_{\mathrm{p})}\right.\end{array}$ & $\mathrm{J} / \mathrm{kgK}$ & 4193 & 4179 \\
\hline $\begin{array}{l}\text { Thermal } \\
\text { conductivity }(\mathrm{k})\end{array}$ & $\mathrm{W} / \mathrm{mK}$ & 0.668 & 0.6316 \\
\hline $\begin{array}{l}\text { Dynamic } \\
\text { viscosity }(\mu)\end{array}$ & $\mathrm{Ns} / \mathrm{m}^{2}$ & 0.0003746 & 0.0006566 \\
\hline Density $(\rho)$ & $\mathrm{Kg} / \mathrm{m}^{3}$ & 1000 & 1000 \\
\hline
\end{tabular}

\subsubsection{Hydraulic Diameter}

The hydraulic diameter is defined as the ratio of the cross sectional area of the channel to the wetted perimeter of the channel.

$$
D_{e}=2 b
$$

$$
\begin{aligned}
& =2 \times 0.007 \\
& =0.014 \mathrm{~m}
\end{aligned}
$$

\subsubsection{Flow Area for Water:}

It is given by,

$$
A=N W b
$$

Where,

$A=$ flow area for water in $\mathrm{m}^{2}, \mathrm{~N}=$ number of water chambers, $\mathrm{W}=$ width of plate in $\mathrm{m}$,

$\mathrm{b}=$ distance between two plates in $\mathrm{m}$

\section{The flow area for hot water}

$$
A_{h}=N_{h} W b
$$

Here, $\mathrm{N}_{\mathrm{h}}=7, \mathrm{~W}=0.25 \mathrm{~m}, \mathrm{~b}=0.007 \mathrm{~m}$

$$
\begin{gathered}
=7 \times 0.25 \times 0.007 \\
A_{h}=0.01225 \mathrm{~m}^{2}
\end{gathered}
$$

The flow area for hot water

$$
A_{c}=N_{c} W b
$$

Here, $\mathrm{N}_{\mathrm{h}}=8, \mathrm{~W}=0.25 \mathrm{~m}, \mathrm{~b}=0.007 \mathrm{~m}$

$$
\begin{gathered}
=8 \times 0.25 \times 0.007 \\
A_{c}=0.014 \mathrm{~m}^{2}
\end{gathered}
$$

\subsubsection{Velocity of Water}

$$
V=\frac{m}{A \rho}
$$

Where, $\mathrm{V}=$ velocity of hot water in $\mathrm{m} / \mathrm{s}$, $\mathrm{m}=$ mass flow rate in $\mathrm{Kg} / \mathrm{s}, \mathrm{A}=$ flow area for water in $\mathrm{m}^{2}$, $\rho=$ density of water in $\mathrm{Kg} / \mathrm{m}^{3}$

For hot water,

$$
V_{h}=\frac{m_{h}}{A_{h} \rho_{h}}
$$

Here, $m_{h}=0.3 \mathrm{Kg} / \mathrm{s}, \mathrm{A}_{\mathrm{h}}=0.01225 \mathrm{~m}^{2}, \rho_{\mathrm{h}}=1000 \mathrm{Kg} / \mathrm{m}^{3}$

$$
\begin{aligned}
& =\frac{0.3}{1000 \times 0.01225} \\
& V_{h}=0.02448 \mathrm{~m} / \mathrm{s}
\end{aligned}
$$

For cold water

$$
V_{c}=\frac{m_{c}}{A_{c} \rho_{c}}
$$

Here, $\mathrm{m}_{\mathrm{c}}=0.3 \mathrm{Kg} / \mathrm{s}, \mathrm{A}_{\mathrm{c}}=0.014 \mathrm{~m}^{2}, \rho_{\mathrm{c}}=1000 \mathrm{Kg} / \mathrm{m}^{3}$

$$
\begin{aligned}
& =\frac{0.3}{0.014 \times 1000} \\
& =0.02142 \mathrm{~m} / \mathrm{s}
\end{aligned}
$$

\subsubsection{Reynolds Number}

Reynolds number is defined as,

$$
R e=\frac{\rho V D_{e}}{\mu}
$$

Where, $\mathrm{Re}=$ Reynolds number,

$\mathrm{D}_{\mathrm{e}}=$ hydraulic diameter in $\mathrm{m}, \mathrm{V}=$ velocity of water in $\mathrm{m} / \mathrm{s}$, $\rho_{=}$density of water in $\mathrm{Kg} / \mathrm{m}^{3}$ $\mu=$ Dynamic viscosity in Ns $/ \mathrm{m}^{2}$

For hot water:

$$
R e_{h}=\frac{\rho_{h} V_{h} D_{e}}{\mu_{h}}
$$

Here, $\rho_{\mathrm{h}}=1000 \mathrm{Kg} / \mathrm{m}^{3}, \mathrm{~V}_{\mathrm{h}}=0.02448 \mathrm{~m} / \mathrm{s}, \mathrm{D}_{\mathrm{e}}=0.014 \mathrm{~m}$, $\mu_{\mathrm{h}}=0.0003746 \mathrm{Ns} / \mathrm{m}^{2}$

$$
=\frac{1000 \times 0.02448 \times 0.014}{0.0003746}
$$

$$
R e_{h}=914.89
$$


For cold water:

$$
R e_{c}=\frac{\rho_{c} V_{c} D_{c}}{\mu_{c}}
$$

Here, $\rho_{\mathrm{c}}=1000 \mathrm{Kg} / \mathrm{m}^{3}, \mathrm{~V}_{\mathrm{c}}=0.02142 \mathrm{~m} / \mathrm{s}, \mathrm{D}_{\mathrm{e}}=0.014 \mathrm{~m}$ $\mu_{\mathrm{h}}=0.0003746 \mathrm{Ns} / \mathrm{m}^{2}$

$$
\begin{gathered}
=\frac{1000 \times 0.02142 \times 0.014}{0.0006566} \\
R e_{c}=456.71
\end{gathered}
$$

\subsubsection{Prandlt Number}

Prandlt number is defined as,

$$
\operatorname{Pr}=\frac{\mu C_{p}}{k}
$$

$\mu=$ Dynamic viscosity in $\mathrm{Ns} / \mathrm{m}^{2}$,

$\mathrm{C}_{\mathrm{p}}=$ specific heat capacity of water $\mathrm{J} / \mathrm{Kg} \mathrm{K}$

$\mathrm{k}=$ thermal conductivity of water in $\mathrm{W} / \mathrm{mK}$

For hot water,

$$
P r_{h}=\frac{\mu_{h} C_{p h}}{k_{h}}
$$

Here, $\mu_{\mathrm{h}}=0.0003746 \mathrm{Ns} / \mathrm{m}^{2}, \mathrm{C}_{\mathrm{ph}}=4193 \mathrm{~J} / \mathrm{Kg} \mathrm{K}$, $\mathrm{k}_{\mathrm{h}}=0.668 \mathrm{~W} / \mathrm{mK}$

$$
\begin{gathered}
=\frac{4193 \times 0.0003746}{0.668} \\
\operatorname{Pr}_{h}=2.35
\end{gathered}
$$

For cold water,

$$
P r_{c}=\frac{\mu_{c} C_{p c}}{k_{c}}
$$

Here, $\mu_{\mathrm{c}}=0.0006566 \mathrm{Ns} / \mathrm{m}^{2}, \mathrm{C}_{\mathrm{pc}}=4179 \mathrm{~J} / \mathrm{Kg} \mathrm{K}$, $\mathrm{k}_{\mathrm{c}}=0.6316 \mathrm{~W} / \mathrm{mK}$

$$
\begin{gathered}
=\frac{0.0006566 \times 4179}{0.6316} \\
P r_{c}=4.35
\end{gathered}
$$

\subsubsection{Nusselt Number:}

It is defined as,

$$
N u=\left(\frac{h D_{e}}{k}\right) .
$$

Where, $\mathrm{h}=$ heat transfer coefficient in $\mathrm{W} / \mathrm{m}^{2} \mathrm{~K}$,

$\mathrm{D}_{\mathrm{e}}=$ diameter in $\mathrm{m} . \mathrm{k}=$ thermal conductivity in $\mathrm{W} / \mathrm{mK}$,

Here $\operatorname{Re}<2000$ so taking relation for laminar flow,

$$
N u=0.662 \operatorname{Re}^{0.5} P r^{0.33}
$$

\section{For hot water}

$$
\begin{gathered}
N u_{h}=0.662 R e_{h}{ }^{0.5} P r_{h}{ }^{0.33} \\
h_{h}=(0.662)\left(\frac{k_{h}}{D_{e}}\right) R e_{h}{ }^{0.5} P r_{h}{ }^{0.33}
\end{gathered}
$$

Here, $\mathrm{k}_{\mathrm{h}}=0.668 \mathrm{~W} / \mathrm{mK}, \mathrm{Re}_{\mathrm{h}}=914.89, \mathrm{Pr}_{\mathrm{h}}=2.35$

$$
\begin{gathered}
=0.662 \times\left(\frac{0.668}{0.014}\right) \times(914.89)^{0.5} \times(2.35)^{0.33} \\
h_{h}=1266.61 \mathrm{~W} / \mathrm{m}^{2} . \mathrm{K}
\end{gathered}
$$

Where, $h_{h}$ is the hot fluid heat transfer coefficient

For cold water

$$
\begin{gathered}
N u_{c}=0.662 R e_{c}{ }^{0.5} P r_{c}{ }^{0.33} \\
h_{c}=(0.662)\left(\frac{k_{c}}{D_{e}}\right) R e_{c}{ }^{0.5} P r_{c}{ }^{0.33}
\end{gathered}
$$

Here, $\mathrm{k}_{\mathrm{c}}=0.6316 \mathrm{~W} / \mathrm{mK}, \mathrm{Re}_{\mathrm{c}}=456.71, \mathrm{Pr}_{\mathrm{c}}=4.35$

$$
=(0.662) \times\left(\frac{0.6316}{0.014}\right) \times(456.71)^{0.5} \times(4.35)^{0.33}
$$

$$
h_{c}=1041.41 \mathrm{~W} / \mathrm{m}^{2} \cdot K
$$

Where $h_{c}$ is the cold fluid heat transfer coefficient

\subsubsection{Overall Heat Transfer Coefficient}

The overall heat transfer coefficient for a clean surface is given by,

$$
\frac{1}{U}=\frac{1}{h_{h}}+\frac{t}{k_{p}}+\frac{1}{h_{c}}
$$

Where, $K_{p}$ is the thermal conductivity of the metal plate and $\mathrm{t}$ is its thickness.

Here, $\mathrm{h}_{\mathrm{h}}=1270.17 \mathrm{~W} / \mathrm{m}^{2} . \mathrm{K}, \mathrm{h}_{\mathrm{c}}=1041.41 \mathrm{~W} / \mathrm{m}^{2} . \mathrm{K}$, $\mathrm{K}_{\mathrm{p}}=14 \mathrm{~W} / \mathrm{m}^{2} \mathrm{~K}$

$$
=\frac{1}{1270.1679}+\frac{0.001}{14}+\frac{1}{1041.41}
$$




$$
\begin{aligned}
& \frac{1}{U}=1.8189 \times 10^{-3} \\
& U=549.76 \mathrm{~W} / \mathrm{m}^{2} . K
\end{aligned}
$$

\subsubsection{LMTD}

The logarithmic mean temperature difference is preferably used when the temperature difference varies within the exchanger. It provides an average temperature difference that reflects the difference more accurate compared to what a regular mean temperature difference does. To determine the logarithmic mean temperature difference, inlet and outlet temperatures of the fluid have to be known for both sides of the heat exchanger. It is defined as,

$$
\Theta_{m}=\left[\frac{\left[\left(T_{h 1}-T_{c 2}\right)-\left(T_{h 2}-T_{c 2}\right)\right]}{\ln \left[\frac{\left(T_{h 1}-T_{c 2}\right)}{\left(T_{h 2}-T_{c 2}\right)}\right]}\right]
$$

Where, $\mathrm{T}_{\mathrm{h} 1}=$ hot water inlet temperature

$\mathrm{T}_{\mathrm{h} 2}=$ hot water inlet temperature

$\mathrm{T}_{\mathrm{c} 1}=$ cold water inlet temperature

$\mathrm{T}_{\mathrm{c} 2}=$ cold water inlet temperature

\section{For parallel flow}

$$
=\left[\frac{[(85-30)-(65-50)]}{\ln \left[\frac{85-30}{65-50}\right]}\right]
$$

\subsubsection{Area Required}

$$
Q=U A \Theta m
$$

$$
\begin{gathered}
25158=550 \times A \times 30.78 \\
A=\left(\frac{25158}{550 \times 30.78}\right) \\
A=1.486 \mathrm{~m}^{2}
\end{gathered}
$$

Assume additional for pipe work and side plates So, total area required, $A=1.6 \mathrm{~m}^{2}$

Total no of plates $=16$

Actual heat transfer plates $=14 \times$

Plate dimension $=400 \mathrm{~mm} \times 250 \mathrm{~mm}$

Assume length: plate ratio as 1.8:1

\subsection{Experimental Setup}

\subsubsection{Test Setup}

The experimental setup consists of plate heat exchanger, thermometer, reservoirs, stop watch, flow rate measuring flask. The heat exchanger has total 16 plates and it is constructed using stainless steel 304. Each plate is flat and has thickness of $1 \mathrm{~mm}$. The total heat transfer area is $1.4 \mathrm{~m}^{2}$. The heat exchanger is designed for $85^{\circ} \mathrm{C}$ temperature and $120 \mathrm{~mm}$ pack length. It has height of $400 \mathrm{~mm}$, width of 200 $\mathrm{mm}$ and gap between two plates is $7 \mathrm{~mm}$. External pipes are used to carry hot and cold water streams. Inlet pipes are connected to bottom side while outlet pipes are connected to top side of exchanger. Cold fluid is supplied at room temperature. Fluid flow varied by ball valves and measured between 0.1 to $1 \mathrm{Kg} / \mathrm{sec}$. Thermometers are placed to measure inlet and outlet temperatures of hot and cold water.

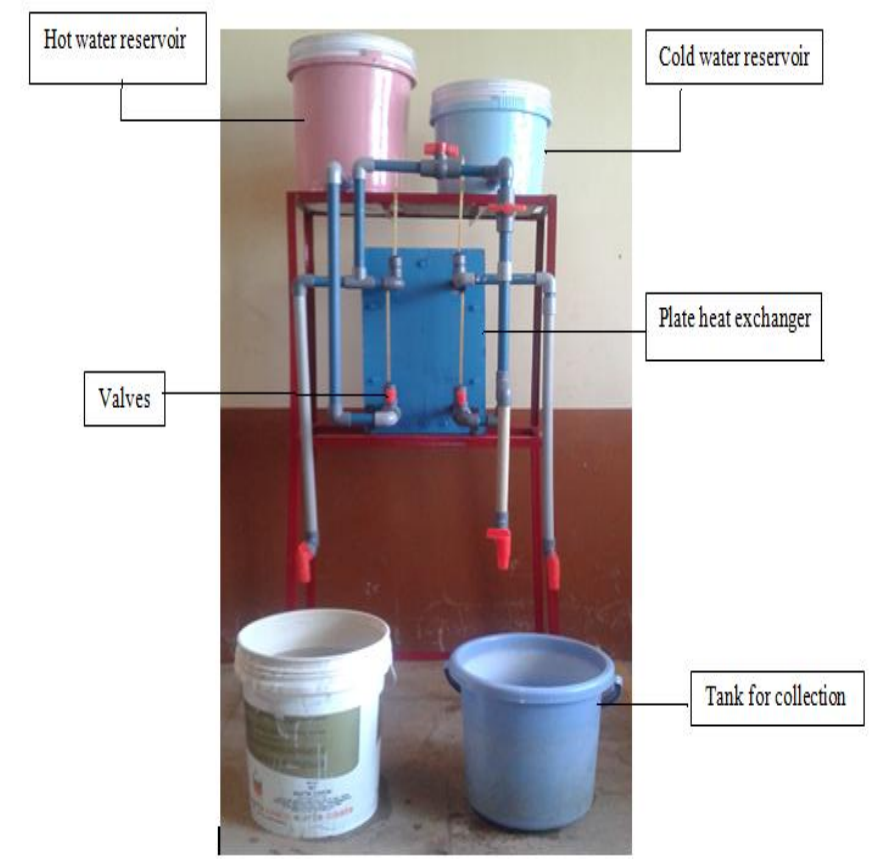

\subsubsection{Test Procedure}

The plate heat exchanger with flat plates is used for trials. The fluids used are hot and cold water. Two flow arrangements implemented which are parallel flow and counter flow. Trials conducted with different mass flow rate of hot and cold water and also hot water inlet flow rate was kept constant while cold water inlet flow rate varied. Procedure repeated for getting more accurate results and results plotted.

\section{Assumptions:}

- The plate heat exchanger operates under steady state conditions,

- No phase change occurs; both fluids are single phase and are unmixed,

- Heat losses to surrounding are negligible,

- The temperature in the fluid streams is uniform,

- The fluids have constant specific heats, 
- The fouling resistance is negligible,

- $\quad$ Pressure drop across heat exchanger is negligible.

\section{RESULTS AND DISCUSSION}

For water to water heat transfer different results are plotted based on different parameters such as overall heat transfer coefficient, exchanger effectiveness, NTU, heat capacity ratio, Reynolds number.

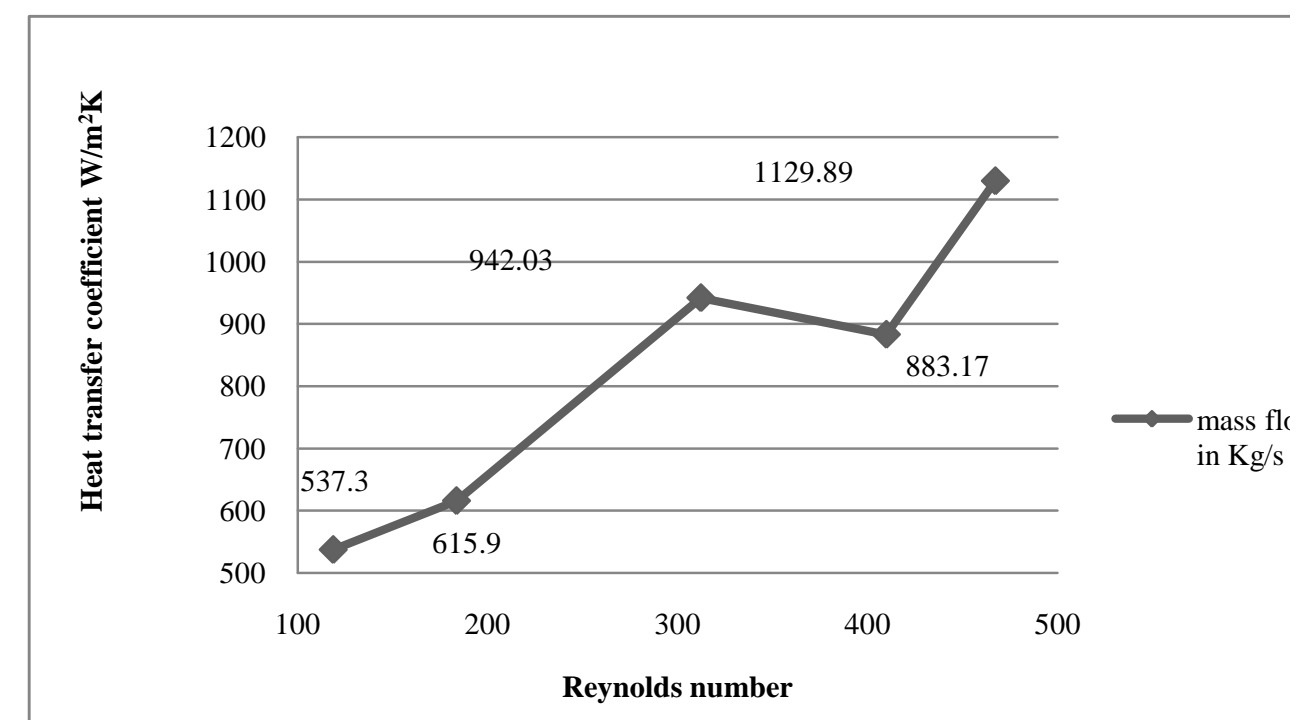

Chart -1: Heat transfer coefficient Vs Reynolds number

Chart-1 shows the variation of convective heat transfer coefficient with Reynolds number. From chart-1 it observed that, heat transfer coefficient increases with Reynolds number. Increase in Reynolds number is an indication that flow is becoming more turbulent and results into higher heat transfer rates.

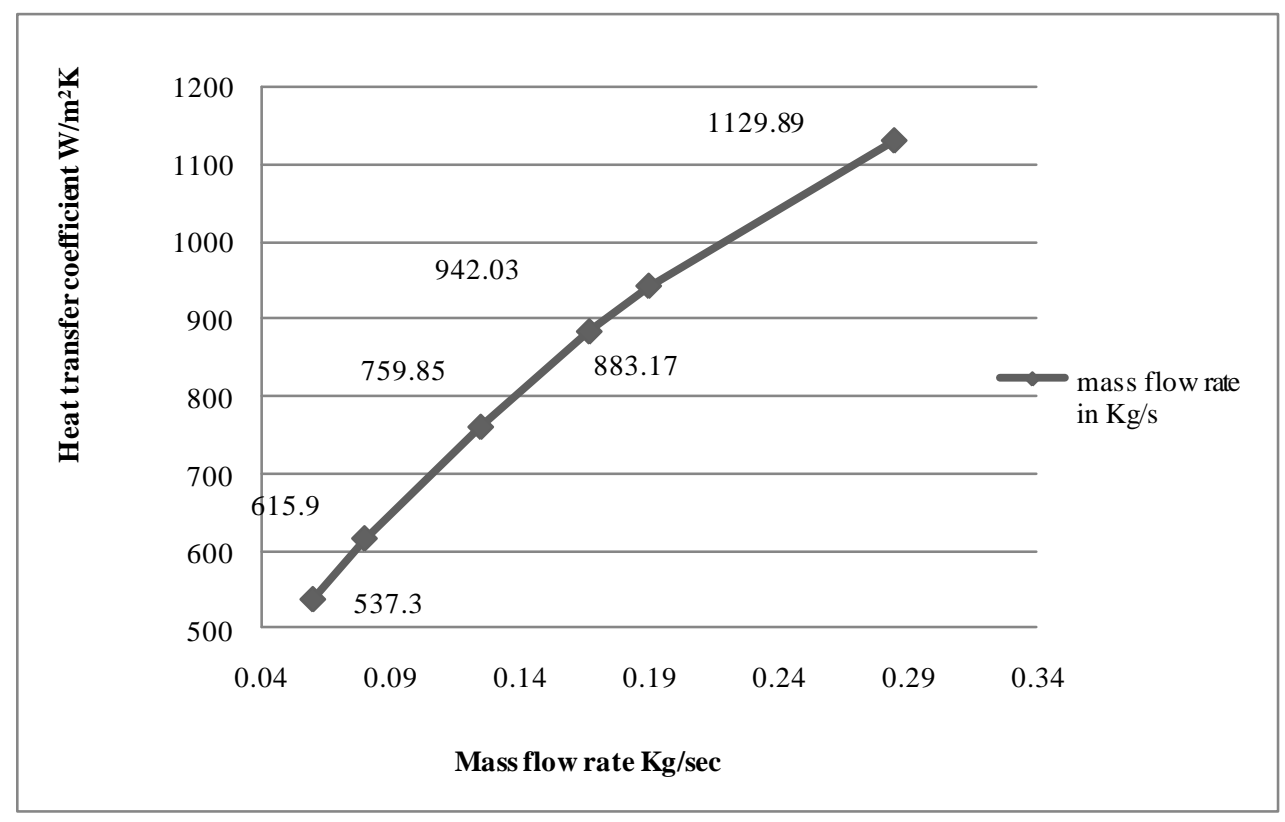

Chart -2: Mass flow rate Vs Heat transfer coefficient

Chart-2 shows variation of convective heat transfer coefficient with respect to mass flow rate. Increase in mass flow rate results into increase in flow velocity of fluid, so
Reynolds number increases which ultimately increases heat transfer rate. 


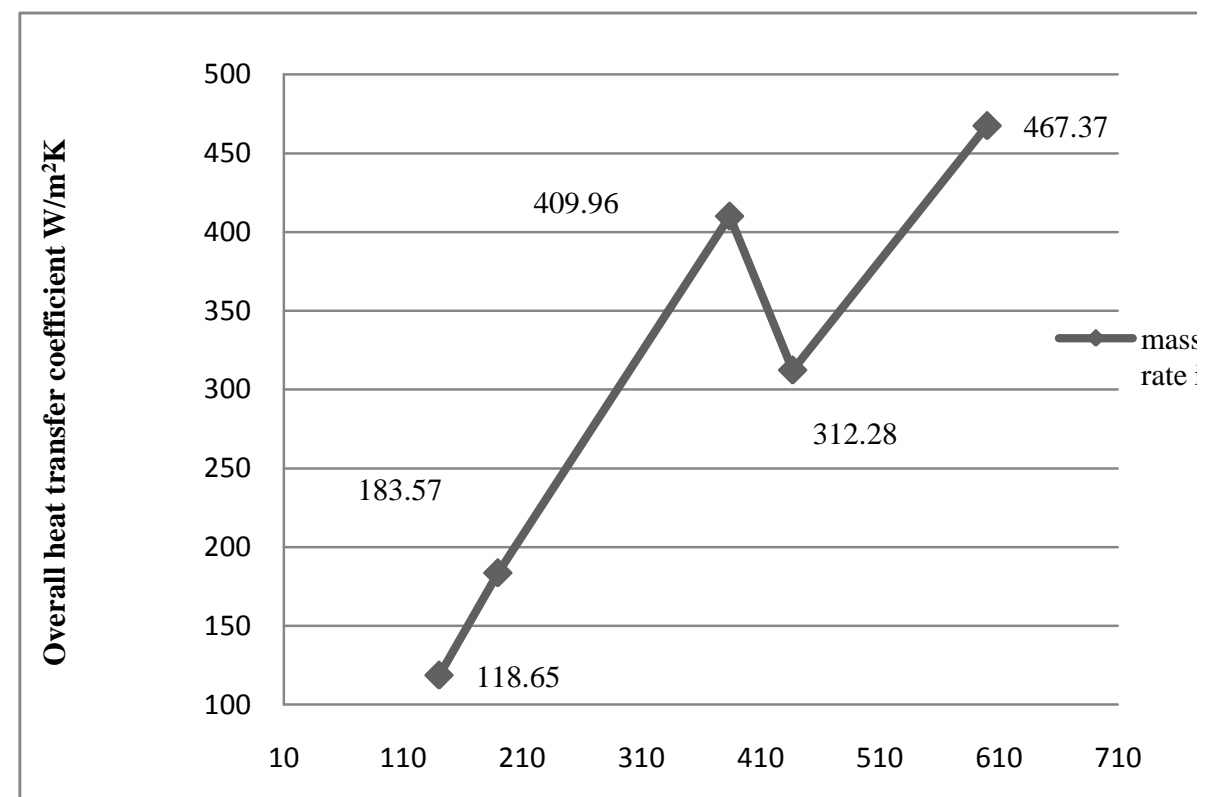

Chart -3: Reynolds number Vs Overall heat transfer coefficient

Chart-3 shows the variation of overall heat transfer coefficient with Reynolds number. From chart-3, it is seen that, overall heat transfer coefficient increases with
Reynolds number. Overall heat transfer coefficient is also dependant on convective heat transfer coefficient so increase in Reynolds number results into higher heat transfer rates.

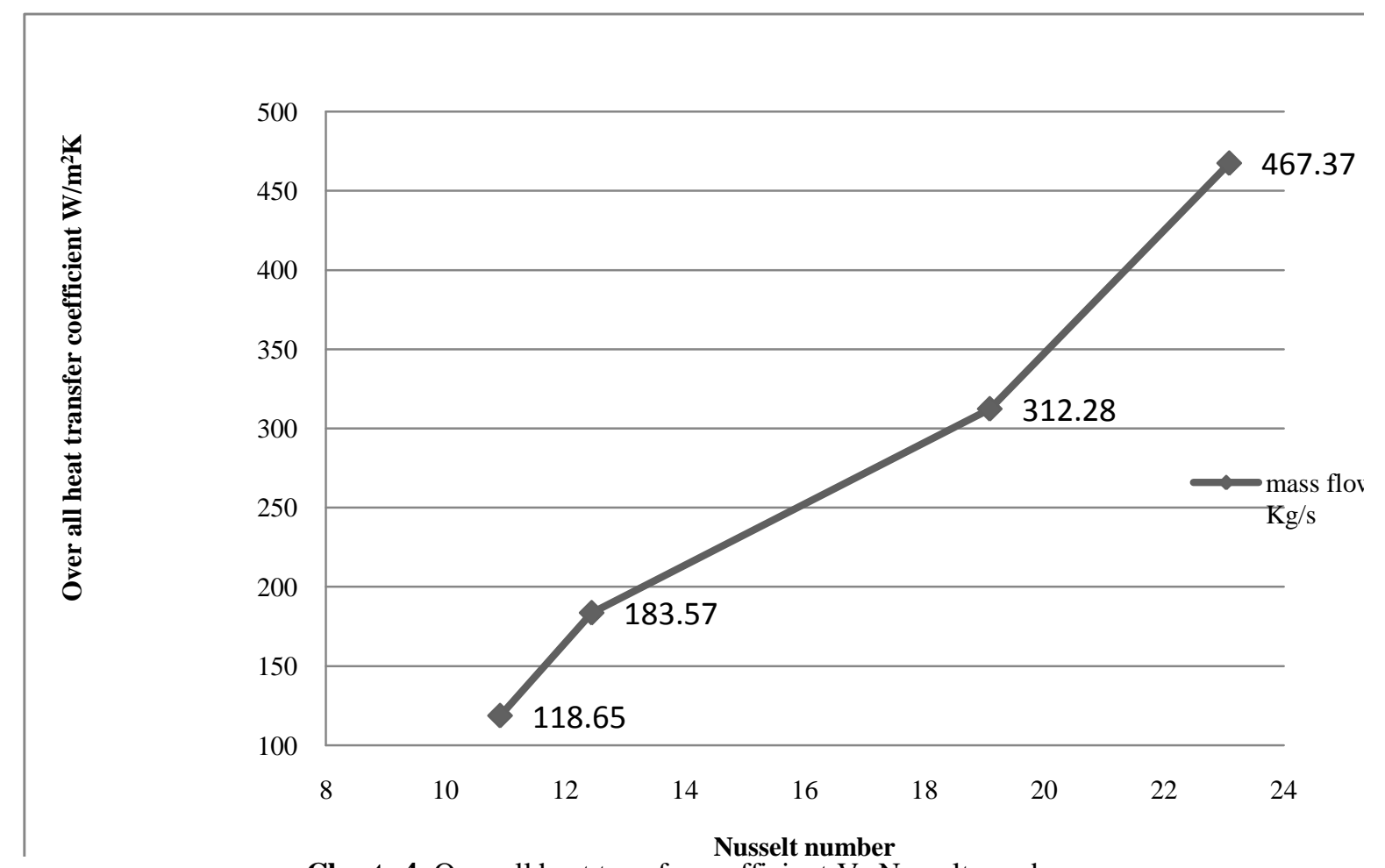

Chart -4: Over all heat transfer coefficient Vs Nusselt number

This chart shows the effect of Nusselt number on overall heat transfer coefficient. Nusselt number is function of Reynolds number so, as Nusselt number increases overall heat transfer coefficient increases. 


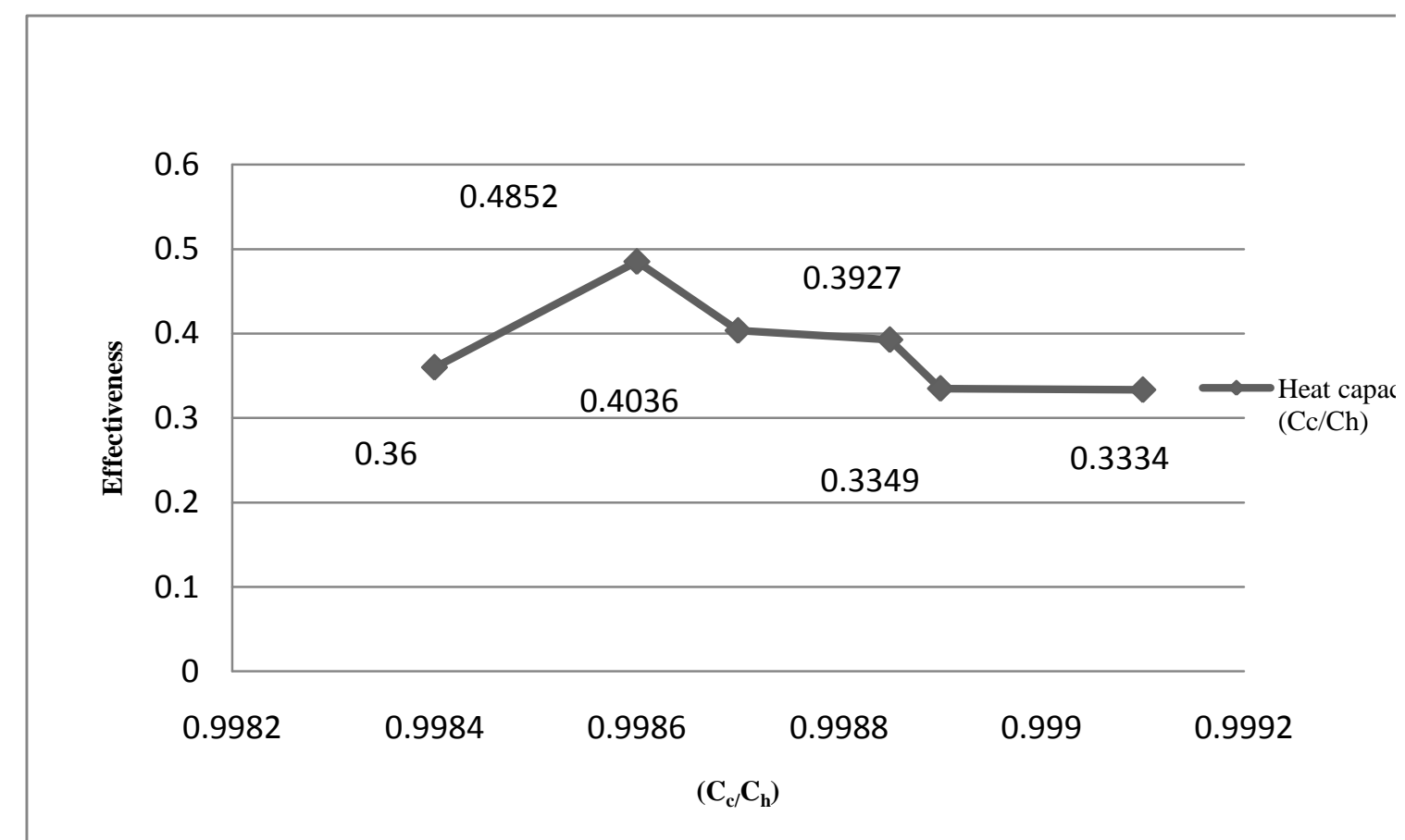

Chart-5: Effectiveness Vs $\left(\mathrm{C}_{\mathrm{c}} \mathrm{C}_{\mathrm{h}}\right)$

Chart-5 shows effect of heat capacity ratio on effectiveness of plate heat exchanger. It is observed that, there is slight variation in effectiveness with increase in heat capacity ratio.

\section{CONCLUSION}

The main focus of this research work is to investigate experimentally the performance of plate heat exchanger with parallel flow arrangement with regard to heat exchanger effectiveness, overall heat transfer coefficient, convective heat transfer coefficient, mass flow rate, and Reynolds number. The following are the results of experimental investigation:

- $\quad$ Convective heat transfer coefficient increases with increase in mass flow rate, also overall heat transfer coefficient increases with increase in Reynolds number. This can be attributed to more turbulent flow.

- Effectiveness of heat exchanger changes slightly when there is change in heat capacity ratio. Maximum effectiveness achieved with parallel flow arrangement is 0.4852 .

This experimental investigation of plate heat exchanger can be extended with counter flow arrangement and water as working fluid. This work can also be extended for use of nano-fluids as working fluid for heat exchanger.

\section{REFERENCES}

[1]. R.K. Shah and S. G. Kandilkar, "The influence of the number of thermal plates on plate heat exchanger performance", (1989), Journal of Heat Transfer, vol.111, pp.300-313, ISSN 0167-577
[2]. H. Dardour, S. Mazouz, and A. Bellagi, "Numerical Analysis of Plate Heat Exchanger Performance in CoCurrent Fluid Flow Configuration", World Academy of Science, Engineering and Technology, Vol: 3, 2009-03-29, ISSN 2278-0181.

[3]. Murugesan M.P. and Balasubramanian R. "To Study the Fouling of Corrugated Plate Type Heat Exchanger in the Dairy Industry", Research Journal of Engineering Sciences, Vol. 2(1), 5-10, January (2013) ,ISSN 2278 - 9472

[4]. Murugesan M.P. and Balasubramanian R., "The Experimental Study on Enhanged heat Transfer Performance in Plate Type Heat Exchanger", Research Journal of Engineering Sciences, Vol. 2(2), 16-22, February (2013), ISSN 2278 - 9472

[5]. T K S Sai Krishna, S. G. Rajasekhar, C. Pravarakhya, "Design and Analysis of Plate Heat Exchanger with $\mathrm{CO}_{2}$ and R134a as Working Fluids", International Journal of Mechanical Engineering And Technology, Volume 4, Issue 4, July - August (2013), pp. 311-318, ISSN 0976 - 6340 (Print) ISSN 0976 - 6359

[6]. R K. Shah and D. P. Sekulic, "Fundamentals of Heat Exchanger Design” Journal of Heat Exchangers, (2003). ISBN-0-471-32117

[7]. Kevin M. Lunsford, "Increasing Heat Exchanger Performance", Bryan Research and Engineering, Inc. Technical Papers (March 1998), Vol 2 ISSN-2278-0181

[8]. Karl Larsson, Fredrik Pihlquist, "Methods of Increasing Thermal Efficiency Of a Counter Flow Air to Air Heat Exchanger", Chalmers University of Technology Goteborg, Sweden, Master's Thesis 2011:08

[9]. R.K. Shah, E.C. Subbarao, R.A.Mashelkar, Heat transfer equipment design, hemisphere publishing corporation, USA, 1988 ,pp 231-234, ISBN-0891167293 
[10]. R.C. Sachdeva, Fundamentals of Engineering Heat and Mass Transfer, New age International Publishers, 2008, pp .491- 528, ISBN (13) 978-81-224-2138-5, ISBN(10) 81224-2138-5

\section{BIOGRAPHIES}

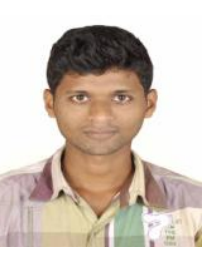

Shahanawaj Kasam Tambe, studying final year mechanical engineering and working on project "Design and Fabrication of Plate Heat Exchanger" under the guidance of Prof. S.B. Khandekar.

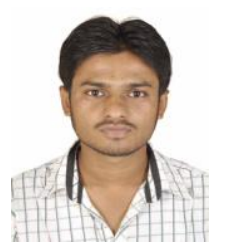

Nitin Tukaram Pandhare, studying final year mechanical engineering and working on project "Design and Fabrication of Plate Heat Exchanger" under the guidance of Prof. S.B. Khandekar

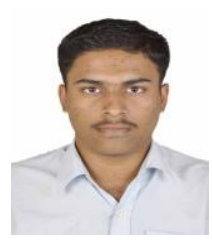

Santosh Jeju Bardeskar, studying final year mechanical engineering and working on project "Design and Fabrication of Plate Heat Exchanger" under the guidance of Prof. S.B. Khandekar.

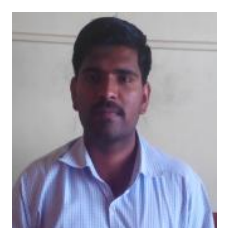

Prof. Khandekar Shailesh B. M.E.(Mechanical Engg.) working as a assistant professor in department of mechanical engineering at Rajendra Mane College of Engineering and Technology, Maharashtra, India.

Devrukh, (University of Mumbai) 